\title{
The expression of Müllerian inhibiting substance/anti-Müllerian hormone type II receptor protein and mRNA in benign, borderline and malignant ovarian neoplasia
}

\author{
JAE YEN SONG ${ }^{1}$, KEUN YOUNG CHEN ${ }^{1}$, SUE YEON KIM ${ }^{1}$, MEE RAN KIM $^{1}$, KI SUNG RYU ${ }^{1}$, \\ JUNG HO CHA ${ }^{2}$, CHANG SUK KANG ${ }^{3}$, DAVID T. MacLAUGHLIN ${ }^{4}$ and JANG HEUB KIM ${ }^{1}$ \\ Departments of ${ }^{1}$ Obstetrics and Gynecology, ${ }^{2}$ Anatomy and ${ }^{3}$ Clinical Pathology, College of Medicine, \\ The Catholic University of Korea, Seoul, Korea; ${ }^{4}$ Pediatric Surgical Research Laboratories, \\ Massachusetts General Hospital, Harvard Medical School, Boston, MA, USA
}

Received January 5, 2009; Accepted March 4, 2009

DOI: 10.3892/ijo_00000288

\begin{abstract}
This study investigated the expression patterns of Müllerian inhibiting substance/anti-Müllerian hormone type II receptor (MIS/AMHRII) and mRNA in various types of ovarian neoplasia and evaluated the clinical significance of MIS/AMH as a biological response modifier for MIS/ AMHR-positive tumors. Reverse transcriptase polymerase chain reaction was used to detect MIS/AMHRII mRNA expression and in situ hybridization and immunohistochemistry were used to localize MIS/AMHRII mRNA and protein expression. The degree of expression was scored from 0 (no staining) to 3 (strong staining). There was no significant difference in expression intensity between MIS/ AMHRII protein and mRNA on all ovarian samples whether benign or malignant. MIS/AMHRII protein and mRNA were weakly expressed on $45.45 \%$ of benign ovarian tumors. In borderline tumors, expression rates of MIS/AMHRII protein and mRNA were $77.78 \%$ with score 1.22 and $55.56 \%$ with score 1 , respectively. In malignant ovarian tumors, expression rates of MIS/AMHRII protein and mRNA were $70 \%$ with score 1.23 and $75 \%$ with score 1.43 , respectively. Among malignant ovarian tumors, sex cord stromal tumors showed the highest expression rate and the strongest intensity of MIS/AMHRII protein and mRNA followed by germ cell tumor and epithelial ovarian tumor. Non-epithelial malignant tumors showed stronger expression than that of epithelial tumors $(\mathrm{P}<0.05, \mathrm{P}<0.001$, respectively). In serous borderline malignant and malignant tumors, MIS/AMHRII protein and mRNA expression was 63.64 and $81.82 \%$ with expression intensity
\end{abstract}

Correspondence to: Dr Jang Heub Kim, Department of Obstetrics and Gynecology, College of Medicine, The Catholic University of Korea, \#62 Yeouido-dong, Yeongdeungpo-gu, Seoul 150-713, Korea E-mail: janghkim@catholic.ac.kr

Key words: Müllerian inhibiting substance, Müllerian inhibiting substance/anti-Müllerian hormone type II receptor, ovarian neoplasia, immuno-histochemistry, in situ hybridization of 1.27 and 1.46 , respectively, which were not statistically different from non-epithelial malignant tumors. MIS/AMHRII and MIS/AMHRII mRNA demonstrate significantly variable expression among different ovarian tumor types. Non-epithelial cell tumors show higher expression than those of epithelial cell tumors. The highest expression rate and intensity were observed on sex cord stromal tumors. MIS/AMHRII expression was not different according to the differentiation, but showed tissue-type specificity. These data support that MIS/AMH may be used as a biological modifier or therapeutic modulator in MIS/AMHRII-expressed ovarian tumors.

\section{Introduction}

Müllerian inhibiting substance (MIS), also known as antiMüllerian hormone (AMH), is a 140 kilodalton glycoprotein composed of 535 amino acids and belongs to TGF- $\beta$ multigene family along with TGF- $\beta$, inhibin, activin, bone morphogenetic protein (BMP) and growth and differentiation factor (GDF). MIS/AMH is known to play an important role in sexual differentiation in males. It is produced in immature Sertoli cells in male embryos and binds to MIS/AMH receptors in primordial Müllerian ducts to cause regression of female reproductive structures that are the precursors to the uterus, fallopian tubes and upper vagina (1). It is also known to play a role in fetal lung maturation (2). MIS/AMH is nearly undetectable in the fetal and postnatal ovary. But after puberty, granulosa cells of ovary start to produce MIS/AMH and maintain similar level in follicular fluid and serum as found in testes $(1,3)$. It is thought to be involved in follicular development and inhibition of steroid hormone production in reproductive women (4-6).

Several cellular and animal studies have demonstrated that MIS/AMH not only plays a significant role in embryonic sexual development, but also causes growth inhibition in cells expressing MIS/AMH receptors. Behringer et al (7) showed that in transgenic female mice, overexpressing MIS/ AMH causes abnormal ovarian development in addition to Müllerian duct regression. Since most common ovarian cancers are of coelomic epithelial origin which is the same embryonic origin as Müllerian ducts and MIS/AMH causing 
the regression of Müllerian ducts, MIS/AMH is expected to inhibit ovarian cancer growth. Purified recombinant human MIS/AMH causes the growth inhibition of ovarian cell lines in vivo and in vitro via MIS/AMH receptor-mediated mechanism (8-11). Several lines of evidence suggest that MIS/AMH inhibits the growth in tissue and cell lines of other MIS/AMH receptor-expressed gynecological malignancies such as cervical, endometrial and breast cancers (12-14). Thus, there are ongoing studies on MIS/AMH as a potential tissue-specific modulator for cancer therapy in malignancy expressing MIS/AMH receptors.

MIS/AMH receptor is a heteromeric complex consisting of type I and type II transmembrane serine/threonine kinases. MIS/AMH binds to MIS/AMH type II receptor (MIS/ AMHRII) which binds a type I receptor (MIS/AMHRI). Current studies suggest that MIS/AMHRI is an activin receptor-like kinase (ALK) ligand such as BMP and GDF type I receptors of TGF- $\beta$ family (15-17). The growth inhibitory function of MIS/AMH begins with binding to MIS/AMHRII and phosphorylation of MIS/AMHRI causing a cascade of intracellular signaling (18-21). Activated MIS/ AMHRI triggers a signaling cascade of intracellular Smad or ß-catenin/lymphoid enhancer factor-1 (LEF-1) complex $(19,22,23)$. Other studies suggest that MIS/AMH inhibits the cell growth by different cellular signaling pathways involving cyclin-dependent kinase inhibitor (CDKI) $(10,13,14)$ or nuclear

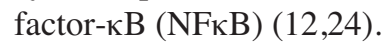

Characterization of expression pattern of MIS/AMH receptors and its mRNA in normal and various ovarian tumor tissues is essential in assessing the role of MIS/AMH as a potential cancer therapeutic biological response modifier. The purpose of this study was to determine the expression pattern of MIS/AMHRII protein and its mRNA in various ovarian tumors of women in order to evaluate the scope of potential targets. By including a wide range of benign and borderline ovarian tumors as well as germ cell and sex cord stromal tumors the present study confirms and extends the conclusions of a recent study of Bakkum-Gamez et al (25).

\section{Materials and methods}

Clinical specimens. Paraffin-fixed 5 normal ovarian tissues, 11 ovarian benign diseases (4 simple cysts, 3 functional cysts, 4 benign epithelial tumors), 9 borderline tumors and 40 malignant tumors (18 epithelial cancers, 13 germ cell tumors, 9 sex cord stromal tumors) were obtained through St. Mary's Hospital Tissue Banks. Seven fresh ovarian tissues (1 normal ovarian tissue, 2 benign cysts, 2 borderline and 2 malignant tumors) were obtained from discarded tissues of patients undergoing surgery. This study was approved by the Institutional Review Board-Human Research Committee at the Hospital (\#SCMC06BR103) and informed consent was obtained from each patient.

Construction of tissue microarray blocks (TMB). Tissue cylinders $3 \mathrm{~mm}$ in diameter were punched from carefully selected histologically representative regions of each paraffinembedded donor tissue block including control samples and brought into a recipient paraffin block using a tissue punch instrument.
Tissue preparation. In order to extract the RNA for RT-PCR, a normal ovarian tissue showing corpus luteum and six cases of ovarian tumor were frozen and stored in liquid nitrogen. For in situ hybridization and immunohistochemistry, 5- $\mu \mathrm{m}$ thick sections from TMB were prepared on the slides (Probe on slide, Fisher Scientific Co., Pittsburgh, PA).

RNA extraction and reverse transcription $(R T)$. Total RNA was isolated using RNA tissue kit (Boehringer Mannheim $\mathrm{GmbH}$, Mannheim, Germany) and first-strand cDNA was reverse-transcribed using RT kit (Boehringer Mannheim) according to the manufacturer's instruction. The reaction products were then stored $-20^{\circ} \mathrm{C}$ before next procedure.

$R T$-PCR. cDNA products were amplified using Takara PCR amplification kit (Takara Shuzo Corp., Shiga, Japan). Amplification started with denaturation at $94^{\circ} \mathrm{C}$ for $4 \mathrm{~min}$ followed by 30 cycles of $94^{\circ} \mathrm{C}$ for $1 \mathrm{~min}, 58^{\circ} \mathrm{C}$ for $1 \mathrm{~min}$ and $72^{\circ} \mathrm{C}$ for $1 \mathrm{~min}$. The sequences of primers for PCR were as follows: upstream primer 5'-gacactgggagagctgctagatac-3' (MIS/AMHRII cDNA; Gene Bank, Accession No. AF172932; sequence 174-197) and downstream primer 5'-gcactctgtagttct ttcgctgta-3' (sequence 572-595). Four $\mu 1$ of PCR product was electrophoresed to examine the band size.

Immunohistochemistry. Immunohistochemistry for MIS/AMH type II receptor was processed using a fast temperaturecontrolled machine, microprobe immunostaining station (Biomeda Co., Foster City, CA). Briefly, the slides were autoclaved at $121^{\circ} \mathrm{C}$ for $10 \mathrm{~min}$ to retrieve antigenic site. The slides were then treated with $3 \% \mathrm{H}_{2} \mathrm{O}_{2}$ for $5 \mathrm{~min}$. After treatment with normal rabbit serum, the slides were incubated with rabbit polyclonal anti-human MIS/AMH type II receptor antiserum (Pediatric Surgical Research Laboratories, Massachusetts General Hospital, Boston, MA) at $4^{\circ} \mathrm{C}$ overnight. The slides were rinsed in T-TBS and incubated with biotinylated anti-rabbit IgG (Zymed Lab. Inc., San Francisco, CA) at $45^{\circ} \mathrm{C}$ for $7 \mathrm{~min}$. After T-TBS rinse, Streptavidin HRP detection system (Zymed Lab. Inc.) was applied to the slides at $45^{\circ} \mathrm{C}$ for $7 \mathrm{~min}$. The slides were treated with 3-amino-9-ethylcarbazole (AEC) for $10 \mathrm{~min}$ at room temperature, counterstained with hematoxylin and then mounted with glycerol gel.

In situ hybridization. Production of RNA probe for MIS/AMH type II receptor in order to get the RNA-probe, a 422-bp PCR product was prepared using the above primers and cloned into the T-Easy vector (Promega Corp., Madison, WI). The digoxingenin (DIG)-labeled sense and antisense human MIS/AMHRII RNA-probe were prepared by in vitro transcription using a DIG RNA labeling kit (Boehringer Mannheim) according to manufacturer's protocol. After dewaxing of slides through the xylene series, they were dried. The dried sections were treated in $0.2 \mathrm{~N} \mathrm{HCI}$ for $20 \mathrm{~min}$ and incubated in $20 \mu \mathrm{g} / \mathrm{ml}$ pepsin $(0.1 \mathrm{~N} \mathrm{HCI})$ for $20 \mathrm{~min}$ at room temperature. The sections were dehydrated with graded ethanol series and dried. Prehybridization and hybridization steps were carried out at $53^{\circ} \mathrm{C}$ for 2 and $15 \mathrm{~h}$, respectively. The prehybridization buffer was composed of $50 \%$ formamide, 4X SSC, $10 \%$ dextran sulfate, 1X Denhardt's solution and 


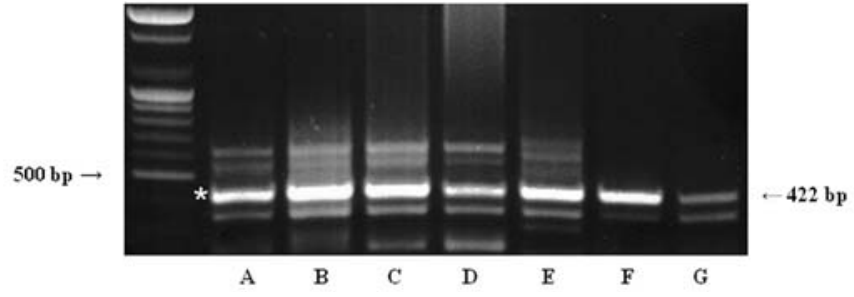

Figure 1. RT-PCR for human MIS/AMH type II receptor from human ovary and ovarian tumors. Bands of 422 bp are detected in the ovary of secretory phase (A), follicular cyst (B), luteal cyst (C), borderline malignant mucinous cystadenoma (D), borderline malignant serous cystadenoma (E), serous adenocarcinoma $(\mathrm{F})$ and endometrioid adenocarcinoma $(\mathrm{G})$.

$1 \mathrm{mg} / \mathrm{ml}$ salmon sperm DNA. The hybridization buffer was identical with the prehybridization buffer except that salmon sperm DNA was substituted by $200 \mathrm{ng} / \mathrm{ml}$ MIS/AMHRII riboprobe. After posthybridization washing, sections were incubated with anti-digoxigenin antiserum conjugated with alkaline phosphatase (Boehringer Mannheim) and histochemical detection was then performed using 4-nitroblue tetrazolium and 5-bromo-4-chloro-3-indolyl-phosphate (Boehringer Mannheim).

Expression scoring system and statistical analysis. The intensity of staining were independently examined by two pathologists on a scale of increasing intensity, 0 (no staining), 1 (weak), 2 (moderate) and 3 (strong staining). Data were analyzed by using Wilcoxon rank sum test, Kruscal-Wallis test and Spearman's rank correlation. A P-value $<0.05$ was considered statistically significant.

\section{Results}

Expression of MIS/AMHRII mRNA by RT-PCR. MIS/AMHRII mRNA expression in various ovarian tissues (1 normal ovarian tissue of secretory phase, 2 benign, 2 borderline, 2 malignant ovarian tumors) was examined by RT-PCR and all tissues showed 422 bp band which was confirmed to be identical to a part (174-595) of human MIS/AMHRII cDNA sequence (Gene Bank, Accession No. AF172932) (Fig. 1).

Expression pattern of MIS/AMHRII by immunohistochemistry. MIS/AMHRII was expressed on 5 normal ovarian tissues, especially in granulosa cells of growing follicle and corpus luteum. The expression intensity of normal tissues was 1.6 on the average (Fig. 2A). For benign ovarian tumors, $45 \%$ (5/11) expressed MIS/AMHR II. There were 3 functional cysts (expression scores $3,1,0), 4$ simple cysts $(1,1,0,0)$, 2 mucinous cystadenomas $(0,0), 1$ serous cystadenoma (1), and 1 mature teratoma (0) with total score 7 and average score 0.64 (Fig. 2B). In borderline malignant tumors, MIS/AMHRII was expressed on $78 \%$ (7/9). There were 6 mucinous $(1,1,1$, $1,0,0)$ and 3 serous tumors $(3,2,2)$ with a total score of 11 and average score 1.22. (Fig. 2C, Table I). Malignant ovarian tumors showed variable expression according to the histological type with $70 \%$ expression on the average (Table II). Epithelial ovarian cancer expressed MIS/AMHRII on $50 \%(9 / 18)$ with a total score of 13 and average score of
0.72. There were 4 mucinous adenocarcinomas $(1,0,0,0), 8$ serous adenocarcinomas $(3,2,1,1,0,0,0,0), 1$ endometrioid carcinoma (1), 2 unclassified adenocarcinomas $(0,0), 2$ clear cell tumors $(1,1)$, and 1 Brenner tumor (2). There was no significant difference in expression according to tumor cellular differentiations (Fig. 2D). MIS/AMHRII was expressed in $77 \%(10 / 13)$ of germ cell tumors with 5 endodermal sinus tumors $(3,3,2,2,0), 6$ dysgerminomas $(3,2,2,2,1,1), 1$ choriocarcinoma (0), and 1 immature teratoma (0). Total expression score was 21 with average score 1.62 (Fig. 2E and F). All 9 samples of sex cord stromal tumors expressed MIS/AMHR II. The samples included 5 granulosa cell tumors $(3,2,1,1,1), 3$ Sertoli-Leydig cell tumors $(2,2,2)$ and 1 thecoma (1) with a total score of 15 and the average score of 1.67 (Fig. 2G and H, Table III).

Expression pattern of MIS/AMHRII mRNA by in situ hybridization. MIS/AMHRII mRNA was expressed on 5 normal ovarian tissues. The expression intensity was 1.6 on average (Fig. 3A). Among benign ovarian tumors, $44.45 \%$ (5/11) expressed MIS/AMHRII mRNA with a total score 9 and an average score of 0.82 with 3 functional cysts (expression scores 3,2,0), 4 simple cysts $(1,1,0,0), 2$ mucinous cystadenomas $(0,0), 1$ serous cystadenoma (2), and 1 mature teratoma (0) (Fig. 3B). Five of $9(55.56 \%)$ borderline malignant tumors expressed MIS/AMHRII mRNA. The expression intensity was $1,1,0,0,0,0$ for 6 mucinous tumors and 3, 2, 2 for 3 serous tumors with a total score of 9 and an average score of 1 (Fig. 3C, Table I). MIS/AMHRII mRNA expression for malignant ovarian tumors varies by histological subtypes with average expression of $75 \%$ (Table II). Epithelial ovarian tumors showed $55.56 \%$ expression (10/18). There were 4 mucinous adenocarcinomas $(1,0,0,0), 8$ serous adenocarcinomas $(3,2,1,1,1,1,0,0), 1$ endometroid carcinoma (1), 2 clear cell tumors $(1,0), 2$ unclassified adenocarcinomas $(0,0)$, and 1 Brenner tumor (1) with a total score of 13 and an average score of 0.72 . There was no significant difference in expression according to tumor cellular differentiations (Fig. 3D). Eleven of 13 (84.62\%) sex cord stromal cell tumors expressed MIS/AMHRII mRNA. Five endodermal sinus tumors $(3,3,2,2,2), 6$ dysgerminomas $(3,3,2,2,1,1), 1$ choriocarcinoma $(0)$, and 1 immature teratoma (0) with total score of 24 , average 1.85 (Fig. 3E and F). All 9 samples of sex cord stromal tumors expressed MIS/AMHRII mRNA with 5 granulosa cell tumors $(3,2,2,2,2), 3$ Sertoli-Leydig cell tumors $(3,3,2)$, and 1 thecoma (1) with a total score of 20, average 2.22 (Fig. 3 and H, Table III).

MIS/AMHRII protein and mRNA expression pattern among different ovarian cancer histological types. There were no statistical differences between MIS/AMHRII protein and mRNA expression in each sample $(\mathrm{r}=0.735)$, thus, protein and mRNA are co-expressed. In comparison, among benign, borderline, and malignant tumors, we observed no significant difference in MIS/AMHRII and mRNA expression either. Among malignant ovarian tumors, MIS/AMHRII protein expression intensity for epithelial tumors was $0.72 \pm 0.21$ which was significantly lower than that of non-epithelial tumors (1.64 $\pm 0.20, \mathrm{P}<0.05)$. MIS/AMHRII mRNA expression in 

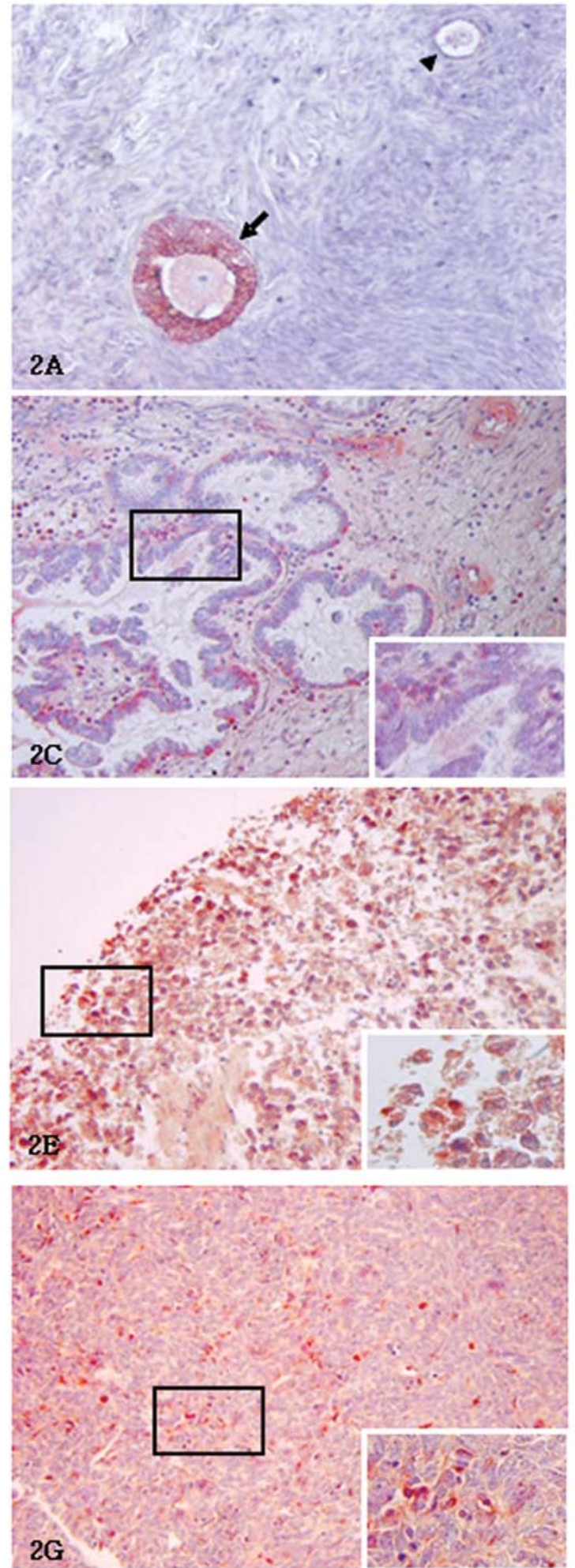
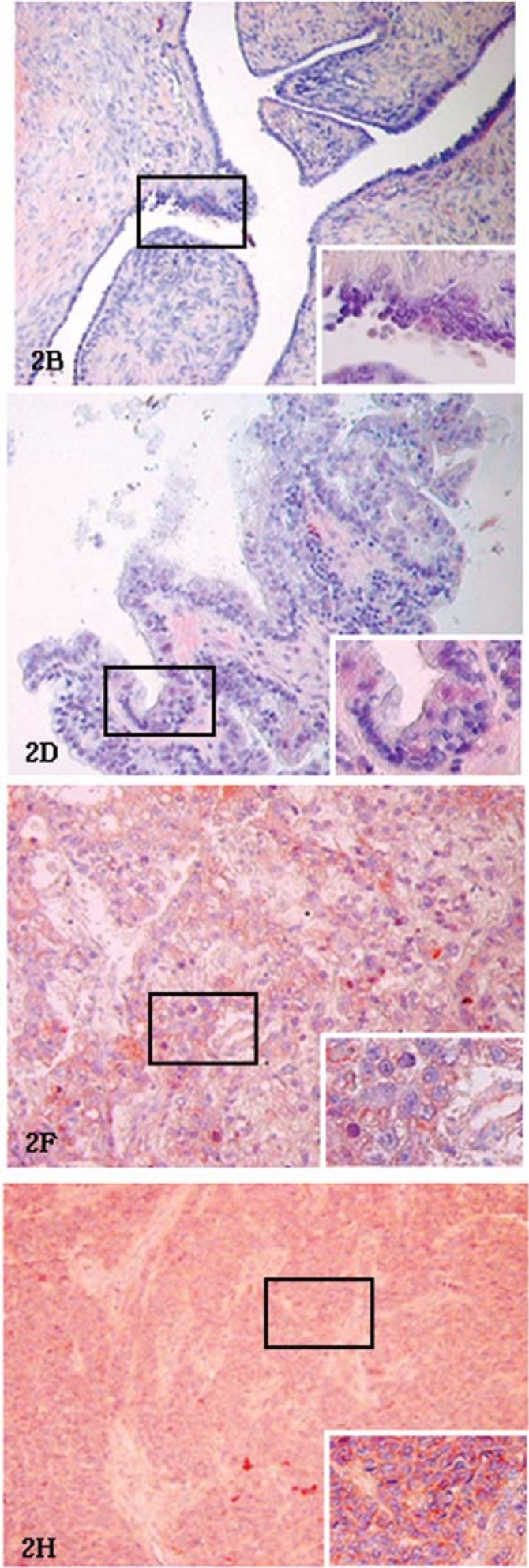

Figure 2. (A) Light micrography from a proliferative phase human ovary. The multiple layered granulosa cells of preantral follicle (arrow) show moderate staining for MIS/AMHRII which is localized specifically in the cell membrane of granulosa cells, but the cuboidal granulosa cells of primary follicle (arrow head) express weakly. Chromogen, AEC. Magnification, x400. (B) Light micrography from human ovarian serous cystadenoma. The epithelial cells weakly express MIS/AMHRII (boxed area), but the stroma fail to express MIS/AMHR II. The inset is a higher magnification image of the boxed area (x400). Chromogen, AEC. Magnification, x200. (C) Light micrography from human ovarian serous cystadenoma borderline malignancy. The papillary epithelium moderately express MIS/AMHRII (boxed area), but the stroma fail to express MIS/AMHRII. The inset is a higher magnification image (x400). Chromogen, AEC. Magnification, x200. (D) Light micrography from human ovarian papillary serous adenocarcinoma, moderately differentiated. The papillary epithelium moderately expresses MIS/AMHRII (boxed area). The inset is a higher magnification of the boxed area (x400). Chromogen, AEC. Magnification, x200. (E) Light micrography from human ovarian dysgerminoma. The cancer cell nests diffusely and strongly express MIS/AMHRII. Right lower figure is higher magnification of the boxed area (x400). Chromogen, AEC. Magnification, x200. (F) Light micrography from human ovarian endodermal sinus tumor. The cancer cells (in the Schiller Duval body and surrounding stroma) diffusely and moderately express MIS/AMHRII. Right lower figure is higher magnification of the boxed area (x400). Chromogen, AEC. Magnification, x200. (G) Light micrography from human ovarian Sertoli-Leydig cell tumor. The Sertoli cells moderately express MIS/AMHR II, and the Leydig cells more strongly express MIS/AMHRII (boxed area). Right lower figure is higher magnification of the boxed area (x400). Chromogen, AEC. Magnification, x200. (H) Light micrography from human ovarian granulosa cell tumor. The granulosa cells in the cancer cell nests strongly express MIS/AMHR II. Right lower figure is higher magnification of the boxed area (x400). Chromogen, AEC. Magnification, x200. 

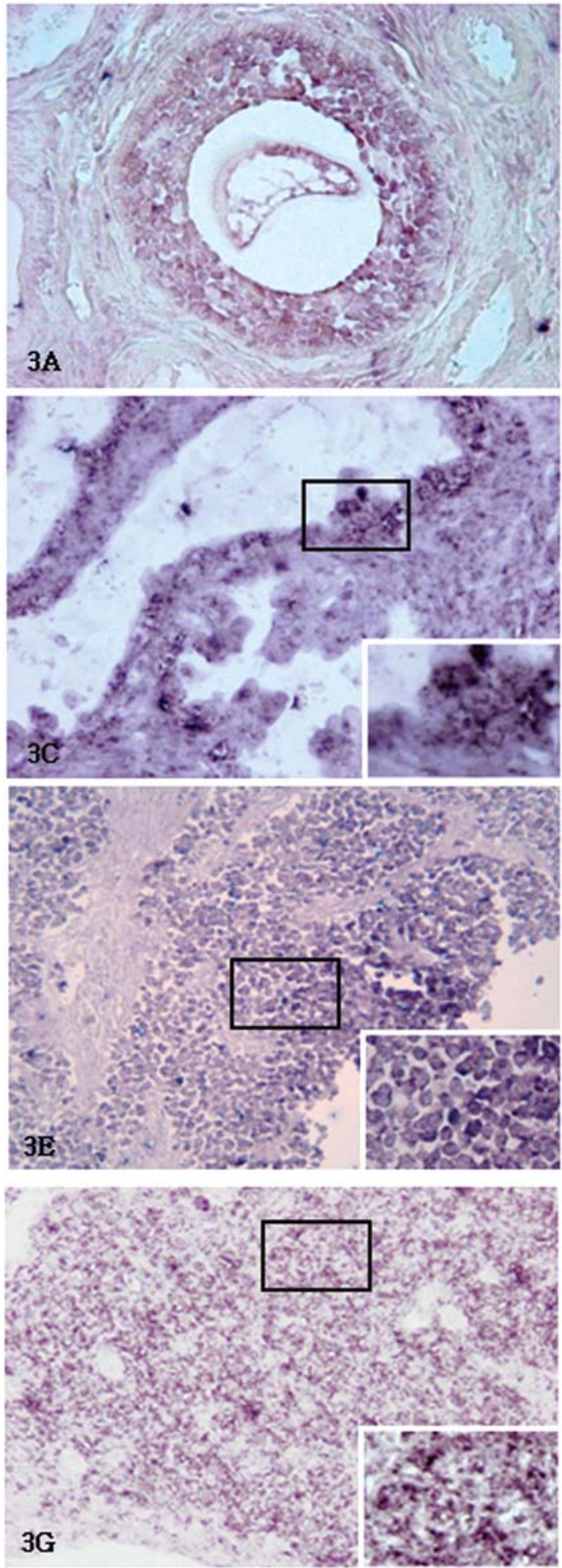
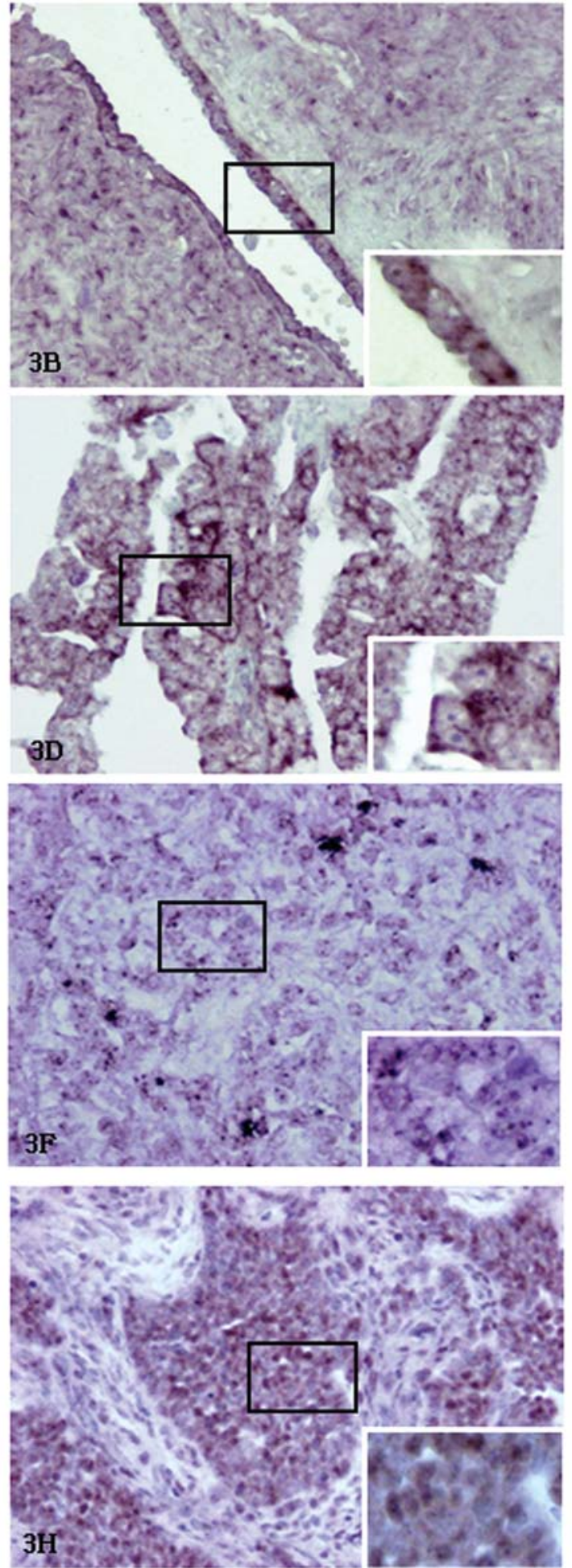

Figure 3. (A) Light micrography from human ovary in proliferative phase. The multiple layered granulosa cells of small sized antral follicle show moderate expression for MIS/AMHRII mRNA. Chromogen, 4-nitroblue tetrazolium chloride/5-bromo-4-chloro-3-indolyl-phosphate (NBT/BCIP). Magnification, x400. (B) Light micrography from human ovarian serous cystadenoma. The epithelial cells moderately express MIS/AMHRII mRNA (boxed area), but the stroma fail to express MIS/AMHRII mRNA. Right lower figure is higher magnification of the boxed area (x400). Chromogen, NBT/BCIP. Magnification, x200. (C) Light micrography from human ovarian serous cystadenoma borderline malignancy. The papillary epithelium moderately express MIS/AMHRII mRNA (boxed area), but the stroma fail to express MIS/AMHRII mRNA. Right lower figure is higher magnification of the boxed area (x400). Chromogen, NBT/BCIP. Magnification, x200. (D) Light micrography from human ovarian papillary serous adenocarcinoma. The papillary epithelium strongly expresses MIS/AMHRII mRNA (boxed area). Right lower figure is higher magnification of the boxed area (x400). Chromogen, NBT/BCIP. Magnification, x200. (E) Light micrography from human ovarian dysgerminoma. The cancer cell nests diffusely and strongly express MIS/AMHRII mRNA. Right lower figure is higher magnification of the boxed area (x400). Chromogen, NBT/BCIP. Magnification, x200. (F) Light micrography from human ovarian endodermal sinus tumor. The cancer cells (in the Schiller Duval body and surrounding stroma) diffusely and moderately express MIS/AMHRII mRNA. Right lower figure is higher magnification of the boxed area (x400). Chromogen, NBT/BCIP. Magnification, x200. (G) Light micrography from human ovarian Sertoli-Leydig cell tumor. The Sertoli cells moderately express MIS/AMHRII mRNA and the Leydig cells more strongly express MIS/AMHRII mRNA (at boxed area). Right lower figure is higher magnification of the boxed area (x400). Chromogen, NBT/BCIP. Magnification, x200. (H) Light micrography from human ovarian granulosa cell tumor. The granulosa cells in the cancer cell nests strongly express MIS/AMHRII mRNA. Right lower figure is higher magnification of the boxed area (x400). Chromogen, NBT/BCIP. Magnification, x200. 
Table I. MIS/AMHRII and MIS/AMHRII mRNA expression in normal ovary and various types of ovarian tumors.

\begin{tabular}{|c|c|c|c|c|c|}
\hline \multirow[b]{2}{*}{ Classification } & \multirow[b]{2}{*}{ Pathology } & \multirow[b]{2}{*}{ Cell type } & \multirow[b]{2}{*}{ Case No. } & \multicolumn{2}{|c|}{ Expression intensity } \\
\hline & & & & MIS/AMHRII & MIS/AMHRII mRNA \\
\hline \multicolumn{6}{|l|}{ Normal } \\
\hline & & & 1 & 1 & 1 \\
\hline & & & 2 & 2 & 2 \\
\hline & & & 3 & 1 & 1 \\
\hline & & & 4 & 2 & 2 \\
\hline & & & 5 & 2 & 2 \\
\hline & Total & & 5 & 8 & 8 \\
\hline \multirow[t]{12}{*}{ Benign } & Functional cyst & Follicular cyst & 1 & 0 & 0 \\
\hline & & & 2 & 1 & 2 \\
\hline & & Luteal cyst & 3 & 3 & 3 \\
\hline & Simple cyst & & 1 & 0 & 1 \\
\hline & & & 2 & 1 & 0 \\
\hline & & & 3 & 1 & 0 \\
\hline & & & 4 & 0 & 1 \\
\hline & Cystadenoma & Mucinous & 1 & 0 & 0 \\
\hline & & & 2 & 0 & 0 \\
\hline & & Serous & 1 & 1 & 2 \\
\hline & Dermoid cyst & & 1 & 0 & 0 \\
\hline & Total & & 11 & 7 & 9 \\
\hline \multirow[t]{10}{*}{ Borderline malignancy } & Mucinous & & 1 & 1 & 1 \\
\hline & & & 2 & 1 & 0 \\
\hline & & & 3 & 1 & 0 \\
\hline & & & 4 & 0 & 0 \\
\hline & & & 5 & 0 & 1 \\
\hline & & & 6 & 1 & 0 \\
\hline & Serous & & 1 & 2 & 2 \\
\hline & & & 2 & 3 & 2 \\
\hline & & & 3 & 2 & 3 \\
\hline & Total & & 9 & 11 & 9 \\
\hline
\end{tabular}

epithelial tumors showed expression intensity of $0.72 \pm 0.19$ while non-epithelial tumors demonstrated a higher expression intensity at $2.00 \pm 0.21(\mathrm{P}<0.001)$. Sex cord stromal tumors showed the highest expression rate and the strongest intensity of MIS/AMHRII protein and mRNA among ovarian tumors $(100 \%, 1.64 \pm 0.24 ; 100 \%, 2.22 \pm 0.31$, respectively) followed by germ cell tumors and epithelial ovarian tumors (Table III). In serous borderline malignant tumors and serous adenocarcinomas MIS/AMHRII protein and mRNA expression was 63.64 and $81.82 \%$ and expression intensity was $1.27 \pm 0.36$ and $1.46 \pm 0.31$, respectively, which were not statistically different than non-epithelial malignant tumors.

\section{Discussion}

Early treatment of ovarian cancer is often difficult because it remains asymptomatic at the early stage and most patients are diagnosed when later stage symptoms such as abdominal pain, abdominal distension due to ascites, urologic complications develop. Ovarian cancer shows good therapeutic response for chemotherapy such as cisplatin, paclitaxel (Taxol), topotecan at early stage but it has high recurrent rate and the 5-year survival for stages III and IV remains at $25 \%$. Thus, a search for a new therapeutic modality that can enhance the effect of existing chemotherapy with less toxicity and more specific targeting has been undertaken $(26,27)$.

MIS/AMH has gained increasing interest as a therapeutic biological agent for ovarian cancer since most of ovarian tumors are originated from coelomic epithelium which is of Müllerian origin and thus, expresses MIS/AMHRII. In vitro MIS/AMH inhibits the growth of ovarian epithelial cell line (HOSE 6-3) and human ovarian cancer cell lines (OVCAR-8) by proliferation of p16 protein, a part of INK4 family (10). In cervical cancer cell line (C33A) MIS/AMH inhibits the cell growth by proliferation of p130 and p107 protein which acts as $G_{1}$ checkpoints (13) and in endometrial cancer cell line (AN3CA) MIS/AMH induces cellular apoptosis by proliferation of p130 and p107, which is p16-independent pocket protein, and decrease of E2F1 (14). On breast cancer 
Table II. MIS/AMHRII and MIS/AMHRII mRNA expression in malignant ovarian tumors.

\begin{tabular}{|c|c|c|c|c|c|}
\hline \multirow[b]{2}{*}{ Classification } & \multirow[b]{2}{*}{ Pathology } & \multirow[b]{2}{*}{ Cell type } & \multirow[b]{2}{*}{ Case No. } & \multicolumn{2}{|c|}{ Expression intensity } \\
\hline & & & & MIS/AMHRII & MIS/AMHRII mRNA \\
\hline \multirow[t]{41}{*}{ Malignancy } & Epithelial & Mucinous & 1 & 0 & 0 \\
\hline & & adenocarcinoma & 2 & 0 & 0 \\
\hline & & & 3 & 1 & 1 \\
\hline & & & 4 & 0 & 0 \\
\hline & & Serous & 1 & 0 & 0 \\
\hline & & adenocarcinoma & 2 & 0 & 0 \\
\hline & & & 3 & 3 & 2 \\
\hline & & & 4 & 0 & 1 \\
\hline & & & 5 & 1 & 1 \\
\hline & & & 6 & 2 & 3 \\
\hline & & & 7 & 1 & 1 \\
\hline & & & 8 & 0 & 1 \\
\hline & & Endometrioid carcinoma & 1 & 1 & 1 \\
\hline & & Clear cell tumor & 1 & 1 & 0 \\
\hline & & & 2 & 1 & 1 \\
\hline & & Adenocarcinoma & 1 & 0 & 0 \\
\hline & & (unclassified) & 2 & 0 & 0 \\
\hline & & Brenner tumor & 1 & 2 & 1 \\
\hline & Germ cell & Endodermal sinus & 1 & 0 & 2 \\
\hline & & tumor & 2 & 2 & 2 \\
\hline & & & 3 & 2 & 3 \\
\hline & & & 4 & 3 & 3 \\
\hline & & & 5 & 3 & 2 \\
\hline & & Dysgerminoma & 1 & 2 & 2 \\
\hline & & & 2 & 1 & 3 \\
\hline & & & 3 & 1 & 1 \\
\hline & & & 4 & 3 & 1 \\
\hline & & & 5 & 2 & 2 \\
\hline & & & 6 & 2 & 3 \\
\hline & & Immature teratoma & 1 & 0 & 0 \\
\hline & & Choriocarcinoma & 1 & 0 & 0 \\
\hline & Sex-cord & Granulosa cell tumor & 1 & 1 & 2 \\
\hline & stroma & & 2 & 2 & 2 \\
\hline & & & 3 & 3 & 3 \\
\hline & & & 4 & 1 & 2 \\
\hline & & & 5 & 1 & 2 \\
\hline & & Sertoli-Leydig cell & 1 & 2 & 2 \\
\hline & & tumor & 2 & 2 & 3 \\
\hline & & & 3 & 2 & 3 \\
\hline & & Thecoma & 1 & 1 & 1 \\
\hline & Total & & 40 & 49 & 57 \\
\hline
\end{tabular}

cell line (T47D) and prostatic cancer cell line (LNCaP) MIS/ AMH binds with MIS/AMHRII and the complex induces the phosphorylation and degradation of $\mathrm{I} \kappa \mathrm{B} \alpha$ and activation of $\mathrm{NF \kappa B}$ subunits (p65 in breast cancer, p50 in prostatic cancer) $(12,21,24,28,29)$.

Serum MIS/AMH is a useful biomarker for the detection of Sertoli cell dysfunction, sexual differentiation disorders and MIS/AMH releasing tumors such as granulosa cell tumor and Sertoli-Leydig cell tumors (30-32). The study of clinical application MIS/AMHRII for predictive marker for metastasis and recurrence of sex cord stromal tumors is ongoing (27). From results of animal studies, it has been shown that injection of purified recombinant human MIS/AMH inhibited the growth of ovarian cell line (OVCAR-8, IGROV-1) (11). Thus, there have been emerging studies on MIS/AMH and MIS/AMHR expression and the relationship to tumors embryogenetically originated from Müllerian ducts specifically ovarian cancer expressing MIS/AMH receptors. 
Table III. The frequency and intensity of MIS/AMHRII and MIS/AMHRII mRNA expression in normal ovary and various types of ovarian tumors.

\begin{tabular}{|c|c|c|c|c|}
\hline \multirow[b]{2}{*}{ Ovarian tumor (cases) } & \multicolumn{2}{|c|}{ MIS/AMHRII } & \multicolumn{2}{|c|}{ MIS/AMHRII mRNA } \\
\hline & Frequency & Expression intensity & Frequency & Expression intensity \\
\hline Benign (11) & $45.45 \%$ & $0.64 \pm 0.28$ & $45.45 \%$ & $0.82 \pm 0.31$ \\
\hline Borderline (9) & $77.78 \%$ & $1.22 \pm 0.32$ & $55.56 \%$ & $1.00 \pm 0.37$ \\
\hline Malignancy (40) & $70.00 \%$ & $1.23 \pm 0.16$ & $75.00 \%$ & $1.43 \pm 0.17$ \\
\hline Epithelial (18) & $50.00 \%$ & $0.72 \pm 0.21^{\mathrm{a}}$ & $55.56 \%$ & $0.72 \pm 0.19^{b}$ \\
\hline Non-epithelial (22) & $86.36 \%$ & $1.64 \pm 0.20^{\mathrm{a}}$ & $90.91 \%$ & $2.00 \pm 0.21^{\mathrm{b}}$ \\
\hline Germ cell (13) & $76.92 \%$ & $1.62 \pm 0.31$ & $84.62 \%$ & $1.85 \pm 0.31$ \\
\hline Sex-cord stromal (9) & $100 \%$ & $1.67 \pm 0.24$ & $100 \%$ & $2.22 \pm 0.31$ \\
\hline
\end{tabular}

Values are the mean \pm standard error. ${ }^{\text {a }}<0.05$, malignant epithelial vs. malignant non-epithelial tumors. ${ }^{\text {b }}<<0.001$, malignant epithelial vs. malignant non-epithelial tumors.

This study was designed to evaluate the expression pattern of MIS/AMHRII in various ovarian tumors. MIS/AMHRII protein and mRNA expression and intensity were noted by immunohistochemistry and in situ hybridization for each tissue sample. We found complete concordance between protein and mRNA expression. We observed that MIS/AMHRII was very often expressed by ovarian benign $(45 \%)$, borderline malignant (78\%) and malignant tumors $(70 \%)$.

These data essentially agree qualitatively with earlier studies $(9,25)$. We also examined, for the first time, cystic disease. Two of three functional cysts express the receptor $(66 \%)$ while half of the simple cysts (2/4) were positive for the MIS/AMH receptor. Results for benign cystadenoma were mixed. No receptor was noted in 2 mucinous tumors but a serous cystadenoma expressed the protein and mRNA. Quantitatively, the expression of receptor protein and mRNA was judged to be weak (mean score 0.82, Table III).

We and others report apparent increased expression of MIS/AMH receptor in malignant disease $(1,25)$. The present study examined borderline malignant ovarian tumors to assess whether there is a graded expression of pattern for the receptor ongoing from benign lesions, through borderline disease, to frank malignancy. Receptor expression frequency nearly doubles (45-78\%) when benign and borderline diseases are compared. There is a tendency for increased receptor protein levels but this trend does not reach statistical significance. Thus, a hallmark of the transition from benign to malignant disease may be the increased MIS/AMHRII expression.

For epithelial malignant tumors, MIS/AMHRII protein and mRNA expression level were 50 and $55.56 \%$, respectively, whereas the values were 86.36 and $90.91 \%$ for non-epithelial malignant tumors (Table III). Furthermore, non-epithelial malignant tumors showed stronger expression rate for MIS/ AMHRII protein and mRNA than that of epithelial tumors $(\mathrm{P}<0.05, \mathrm{P}<0.001$, respectively). In comparison, sex cord stromal tumors had the highest expression for both MIS/ AMHRII and mRNA (100\%). In serous borderline malignant tumors and serous cystadenocarcinoma, MIS/AMHRII and mRNA expression was 63.64 and $81.82 \%$ with expression intensity of $1.27 \pm 0.36$ and $1.46 \pm 0.31$, respectively and these values are essentially the same as the non-epithelial malignant tumors. Our data on serous adenocarcinoma are comparable with previously published studies, however, the results on the frequency of receptor in malignant mucinous tumors are lower $(25 \%)$ than those previously reported (100\%) (25) despite examining similar number of cases. Masiakos et al (9) reported that $89 \%$ ovarian cancer cells and ascites cells from ovarian cancer stage III and IV expressed MIS/AMHRII. Bakkum-Gamez et al (25) stated that $69 \%$ of ovarian epithelial origin cancers expressed MIS/AMHRII and our study essentially agrees with the conclusion that receptor expression is high in malignancies. This apparent high rate of receptor positivity in ovarian cancers makes plausible the idea of using MIS/AMH as a treatment that may be offered to the majority of the cases.

It is noteworthy that our study shows, for the first time, that borderline cases may also be MIS/AMH targets. This same conclusion could also be drawn for the malignant stromal diseases because the overall receptor expression is so high. However, these lesions actually secrete bioactive MIS/AMH and tumors seem refractory to the antiproliferative action of the protein. In fact, a recent study provides a possible explanation namely, defective type I receptors may block MIS/AMH signaling in these cases (33). Interestingly, germ cell tumors also express the MIS/AMH receptor. The overall frequency is higher $(77 \%)$ than in the epithelial malignancies $(50 \%)$. Unlike the other cancers it is unknown whether the receptor is functional.

According to Masiakos et al (9) the frequency of MIS/ AMHRII expression in ascites cells from ovarian cancer stage III, IV patients was similar to that of estradiol receptor expression on breast cancer patients. Masiakos et al (9) and Barbie et al (13) stated that MIS/AMH inhibited the growth of MIS/AMHR expressing ovarian and cervical cancer cell lines and MIS/AMH can inhibit ovarian cell growth by lengthening $G_{1}$ phase of ovarian cancer cells. This suggests that MIS/AMHR could be a potential adjuvant for chemotherapy $(10,25)$. We also could expect better therapeutic effect for those tumors showing high expression of MIS/AMHRII if MIS/AMH were utilized as a potential therapeutic agent. However, as Bakkum-Gamez et al (25) suggest, further investigations for MIS/AMHR expression in other normal 
non-gynecologic tissues are granted for possible side effects in case of clinical application of MIS/AMH as therapeutic agent.

\section{References}

1. MacLaughlin DT and Donahoe PK: Mullerian inhibiting substance: a potential nontoxic, naturally occurring therapeutic agent for certain human cancers. In: Transforming Growth Factor-Beta in Cancer Therapy. Jakowlew S (ed). Humana Press, Totowa (NJ), pp333-353, 2008.

2. Catlin EA, Powell SM, Manganaro TF, Hudson PL, Ragin RC, Epstein J and Donahoe PK: Sex-specific fetal lung development and Müllerian inhibiting substance. Am Rev Respir Dis 141: 466-470, 1990.

3. Lee MM, Donahoe PK, Hasegawa T, Silverma B, Crist GB Best S, Hasegawa Y, Noto RA, Schoenfeld D and MacLaughlin DT: Müllerian inhibiting substance in humans: normal levels from infancy to adulthood. J Clin Endocrinol Metab 81: 571-576, 1996

4. Kim JH, Seibel MM, MacLaughlin DT, Donahoe PK, Ransil BJ, Hametz PA and Richards CJ: The inhibitory effects of Müllerian inhibiting substance on epidermal growth factor induced proliferation and progesterone production of human granulosaluteal cells. J Clin Endocrinol Metab 75: 911-917, 1992.

5. Kuroda T, Lee MM, Ragin RC, Hirobe S and Donahoe PK: Müllerian inhibiting substance production and cleavage is modulated by goandotropins and steriods. Endocrinology 129: 2985-2992, 1991.

6. Baarends WM, Uilenbroek JT, Kramer P, Hoogerbrugge JW van Leeuwen EC, Themmen AP and Grootegoed JA: AntiMüllerian hormone and anti-Müllerian hormone type II receptor messenger ribonucleic acid expression in rat ovaries during postnatal development, the estrous cycle, and gonadotropininduced follicle growth. Endocrinology 136: 4951-4962, 1995

7. Behringer RR, Cate RL, Froelick GJ, Palmiter RD and Brinster RL: Abnormal sexual development in transgenic mice chronically expressing Müllerian inhibiting substance. Nature 345: 167-170, 1990

8. Chin T, Parry RL and Donahoe PK: Human Müllerian inhibiting substance inhibits tumor growth in vitro and in vivo. Cancer Res 51: 2101-2106, 1991.

9. Masiakos PT, MacLaughlin DT, Maheswaran S, Teixeira J, Fuller AF Jr, Shah PC, Kehas DJ, Kenneally MK, Dombkowski DM, Ha TU, Preffer FI and Donahoe PK: Human ovarian cancer, cell lines, and primary ascites cells express the human Müllerian inhibiting substance (MIS/AMH) type II receptor, bind, and are responsive to MIS/AMH. Clin Cancer Res 5: 3488-3499, 1999.

10. Ha TU, Segev DL, Barbie D, Masiakos PT, Tran TT, Dombkowski D, Glander M, Clarke TR, Lorenzo HK, Donahoe PK and Maheswaran S: Müllerian inhibiting substance inhibits ovarian cell growth through an pRb-independent mechanism. J Biol Chem 275: 37101-37109, 2000.

11. Stephen AE, Pearsall LA, Christian BP, Donahoe PK, Vacanti JP and MacLaughlin DT: Highly purified Müllerian inhibiting substance inhibits human ovarian cancer in vivo. Clin Cancer Res 8: 2640-2646, 2002.

12. Segev DL, Ha TU, Tran TT, Kenneally M, Harkin P, Jung M, MacLaughlin DT, Donahoe PK and Maheswaran S: Müllerian inhibiting substance inhibits breast cancer cell growth through an NFкB-mediated pathway. J Biol Chem 275: 28371-28379, 2000.

13. Barbie TU, Barbie DA, MacLaughlin DT, Maheswaran S and Donahoe PK: Müllerian inhibiting substance inhibits cervical cancer cell growth via a pathway involving p130 and p107. Proc Natl Acad Sci USA 100: 15601-15606, 2003.

14. Renaud EJ, MacLaughlin DT, Oliva E, Rueda BR and Donahoe PK: Endometrial cancer is a receptor-mediated target for Müllerian Inhibiting Substance. Proc Natl Acad Sci USA 102: 111-116, 2005

15. Gouedard L, Chen YG, Thevenet L, Racine C, Borie S, Lamarre I, Josso N, Massague J and di Clemente N: Engagement of bone morphogenetic protein type IB receptor and Smad1 signaling by anti-Müllerian hormone and its type II receptor. J Biol Chem 275 : 27973-27978, 2000
16. Clarke TR, Hoshiya Y, Yi SE, Liu X, Lyons KM and Donahoe PK: Müllerian inhibiting substance signaling uses a bone morphogenetic protein (BMP)-like pathway mediated by ALK2 and induces Smad6 expression. Mol Endocrinol 15: 946-959, 2001

17. Visser JA, Olaso R, Verhoef-Post M, Kramer P, Themmen AP and Ingraham HA: The serine/threonine transmembrane receptor ALK2 mediates Müllerian inhibiting substance signaling. Mol Endocrinol 15: 936-945, 2001

18. Teixeira J, Maheswaran S and Donahoe PK: Müllerian inhibiting substance: an instructive developmental hormone with diagnostic and possible therapeutic applications. Endocr Rev 22: 657-674, 2001 .

19. Josso N and di Clemente N: Transduction pathway of antiMüllerian hormone, a sex-specific member of the TGF-beta family. Trends Endocrinol Metab 14: 91-97, 2003.

20. di Clemente N, Josso N, Gouedard L and Belville C: Components of the anti-Müllerian hormone signaling pathway in gonads. Mol Cell Endocrinol 211: 9-14, 2003.

21. Segev DL, Hoshiya Y, Hoshiya M, Tran TT, Carey JL, Stephen AE, MacLaughlin DT, Donahoe PK and Maheswaran S: Müllerian-inhibiting substance regulates NF- $\kappa \mathrm{B}$ signaling in the prostate in vitro and in vivo. Proc Natl Acad Sci USA 99: 239-244, 2002.

22. Xavier F and Allard S: Anti-Mullerian hormone, beta-catenin and Müllerian duct regression. Mol Cell Endocrinol 211: 115-121, 2003.

23. Allard S, Adin P, Gouedard L, di Clemente N, Josso N, Orgebin-Crist MC, Picard JY and Xavier F: Molecular mechanisms of hormone-mediated Müllerian duct regression: involvement of beta-catenin. Development 127: 3349-3360, 2000 .

24. Segev DL, Hoshiya Y, Stephen AE, Hoshiya M, Tran TT, MacLaughlin DT, Donahoe PK and Maheswaran S: Müllerian inhibiting substance regulates $\mathrm{NF}_{\mathrm{B}} \mathrm{B}$ signaling and growth of mammary epithelial cells in vivo. J Biol Chem 276: 26799-26806, 2001.

25. Bakkum-Gamez JN, Aletti G, Lewis KA, Keeney GL, Thomas BM, Navarro-Teulon I and Cliby WA: Müllerian inhibiting substance type II receptor (MIS/AMHIIR): a novel, tissue-specific target expressed by gynecologic cancers. Gynecol Oncol 108: 141-148, 2008.

26. Salhi I, Cambon-Roques S, Lamarre I, Laune D, Molina F, Pugnière M, Pourquier D, Gutowski M, Picard JY, Xavier F, Pèlegrin A and Navarro-Teulon I: The anti-Müllerian hormone type II receptor: insights into the binding domains recognized by a monoclonal antibody and the natural ligand. Biochem $\mathbf{J} 379$ : 785-793, 2004.

27. Salom E, Almeida Z and Mirhashemi R: Management of recurrent ovarian cancer: evidence-based decisions. Curr Opin Oncol 14: 519-527, 2002

28. Hoshiya Y, Gupta V, Segev DL, Hoshiya M, Carey JL, Sasur LM, Tran TT, Ha TU and Maheswaran S: Müllerian inhibiting substance induces NFkB signaling in breast and prostate cancer cells. Mol Cell Endocrinol 211: 43-49, 2003.

29. Gupta V, Carey JL, Kawakubo H, Muzikansky A, Green JE, Donahoe PK, MacLaughlin DT and Maheswaran S: Mullerian inhibiting substance suppresses tumor growth in the C3(1)T antigen transgenic mouse mammary carcinoma model. Proc Natl Acad Sci USA 102: 3219-3224, 2005

30. Gustafson ML, Lee MM, Scully RE, Moncure AC, Hirakawa T, Goodman A, Muntz HG, Donahoe PK, MacLaughlin DT and Fuller AF Jr: Müllerian inhibiting substance as a marker for ovarian sex cord tumor. N Engl J Med 326: 466-471, 1992.

31. Josso N: Pediatric applications of anti-Müllerian hormone research. Horm Res 43: 243-248, 1995.

32. Lane AH, Lee MM, Fuller AF, Kehas DJ, Donahoe PK and MacLaughlin DT: Diagnostic utility of Müllerian inhibiting substance determination in patients with primary and recurrent granulosa cell tumors. Gynecol Oncol 73: 51-55, 1999.

33. Kevenaar ME, Themmen AP, van Kerkwijk AJ, Valkenburg O, Uitterlinden AG, de Jong FH, Laven JS and Visser JA: Variants in the ACVR1 gene are associated with AMH levels in women with polycystic ovary syndrome. Hum Reprod 24: 241-249, 2009. 